ANNA CALVERA

GRACMON - GRUPO DE INVESTIGACIÓN

EN HISTORIA DEL ARTE Y DEL DISEÑO

CONTEMPORÁNEOS

UNIVERSIDAD DE BARCELONA

BARCELONA, ESPAÑA

ANNACALVERA@UB.EDU

\section{The Olympic Games Barcelona '92, an Early and Very Successful Experience in Design Management. A Talk With Jaume Masferrer}

Los JJ.OO. de Barcelona '92, un caso muy temprano y ejemplar de Gestión del Diseño. Una conversación con Jaume Masferrer

25 years ago, Barcelona organised Olympic Games under соов leadership. Design policy and results adopted then really impressed internationally. It might be considered an early example of design management good practices. Design policy concerned iconic buildings as much as humble designs of visual signs, signals, sport devices, tools and even souvenirs. The aim of this article is to display this policy as explained first hand by one of its managers, Mr Jaume Masferrer, then a very young member of СОов. It is thus an exercise of collection data through oral history applied to Design Management.

Jaume Masferrer. Born in Brazil (1960). He has a Bachelor (licenciado) in Business Sciences by ESADE (Barcelona). He has always developed his professional career in the communications area and being director at several Advertising Agencies such as MMLB, Publicis Casadevall Pedreño \& PRG. He was in charge of the promotion, advertising and design management tasks during the organisation of the Olympic Games of Barcelona (1989-1992). At present he manages Confidence\&Communication, its own agency, working for brands such as the Futbol Club Barcelona, the electricity supplier Factor Energia or the Concert Salle Palau de la Musica, among many others.

\section{Introduction: "who was who" at a round table commemorating the twenty years}

In the autumn of 2012, twenty years after the 23rd Olympic Games (19861992) were held in Barcelona in the summer of 1992, a seminar was organised by the Design History Foundation (FHD), jointly with the journal Monografica.org and Design HUB Barcelona, to remember the time and to review the design that was created then.

The second session on the first day was: Design Management: Taking Care of the Look of the BCN'92 Games.

In people's memory and in the history books Barcelona'92 continues to be a story of success and good design. It was worth seeing why and whether it can still be considered as such. Of the three round tables scheduled, one was dedicated to the graphic design projects of the games (the brand image and the pictograph system, the mascot and variations of it, the posters and the promotional material during the Olympiad); another analysed the products and objects that were most emblematic of the games, and, finally, the third gave the design managers a chance to speak, the little-known people who organized, implemented and managed an 
extremely consistent design policy. Those round tables could perfectly be considered research outcomes as far as they tried to register information broadcasting in a method close to Oral History methods. For the rest, to organise the table concerning design management asked much more effort as far as managers working on the City Council or its representative body in charge of management has not been so easy. People are not so well known and it was necessary to look after and find people who were really young at the time of the games and whose work remained hinted behind well-known designers big names.

In 2017, Barcelona's City Council has decided to commemorate the Olympic Games 25th anniversary. Some celebrations have been therefore planned. This is why to explain some hinted experiences concerning design and its management, it is still interesting to know about thinking at a wider public and future design managers.

Indeed, several bodies played a part in the design of Barcelona's Games and the management of the established programme. In the first place, there was the СоOB' 92 itself. The mascot Cobi was named after this body, created especially to run the event. Secondly, there was the Cultural Olympiad, a City Council office or agency that was active from the moment the Games were awarded to Barcelona in 1986 until the opening ceremony on 25th July 1992. Its job was to organise cultural activities on the occasion of the games - in the case of design we should mention the Casa Barcelona exhibition for architects, industrial designers and interior decorators. Finally, there was Barcelona City Council's Sports Department.

At the соОв, a very young Jaume Masferrer was in charge of the promotion, advertising and design of the games. His job consisted of drafting and establishing the briefings relative to everything to do with the games and their image and also the organisation of the ceremonies. He opened the series of speeches at the round table, and his was the one that has given rise to this article because of the overview that he gave.

Quim Larrea and Juli Capella's team worked intensely with the cultural Olympiad and the Sports Department. Back then they were both designers, but above all, critics, feature writers, promoters and design exhibition curators, as well as the publishers of some of the leading design magazines in Barcelona in the 1980 s. At the Cultural Olympiad, the person they dealt with was Isidre Rigau, who, among many other things, was managing the Games' schedule. Together they thought "how to create design in the games"; in other words, they were looking for what could be designed in the world of sport. Larrea and Rigau contacted Guillem Virgili, an industrial designer even younger than them, whose job it was to manage the orders, and control the designs of artefacts and equipment for the different Olympic disciplines.

Quim Larrea spoke next at the round table. Of the many things he said, one that it is worth remembering was the research they did to find all the things, pieces, tools and objects associated with the Olympic disciplines that were not subject to strict regulations. It was therefore thought that they could be redesigned so that, at least in the preparation of the sports fields at Barcelona'92, design would be everywhere; everything would exhibit the design factor and display its basic quality and creativity. He very clearly remem- 


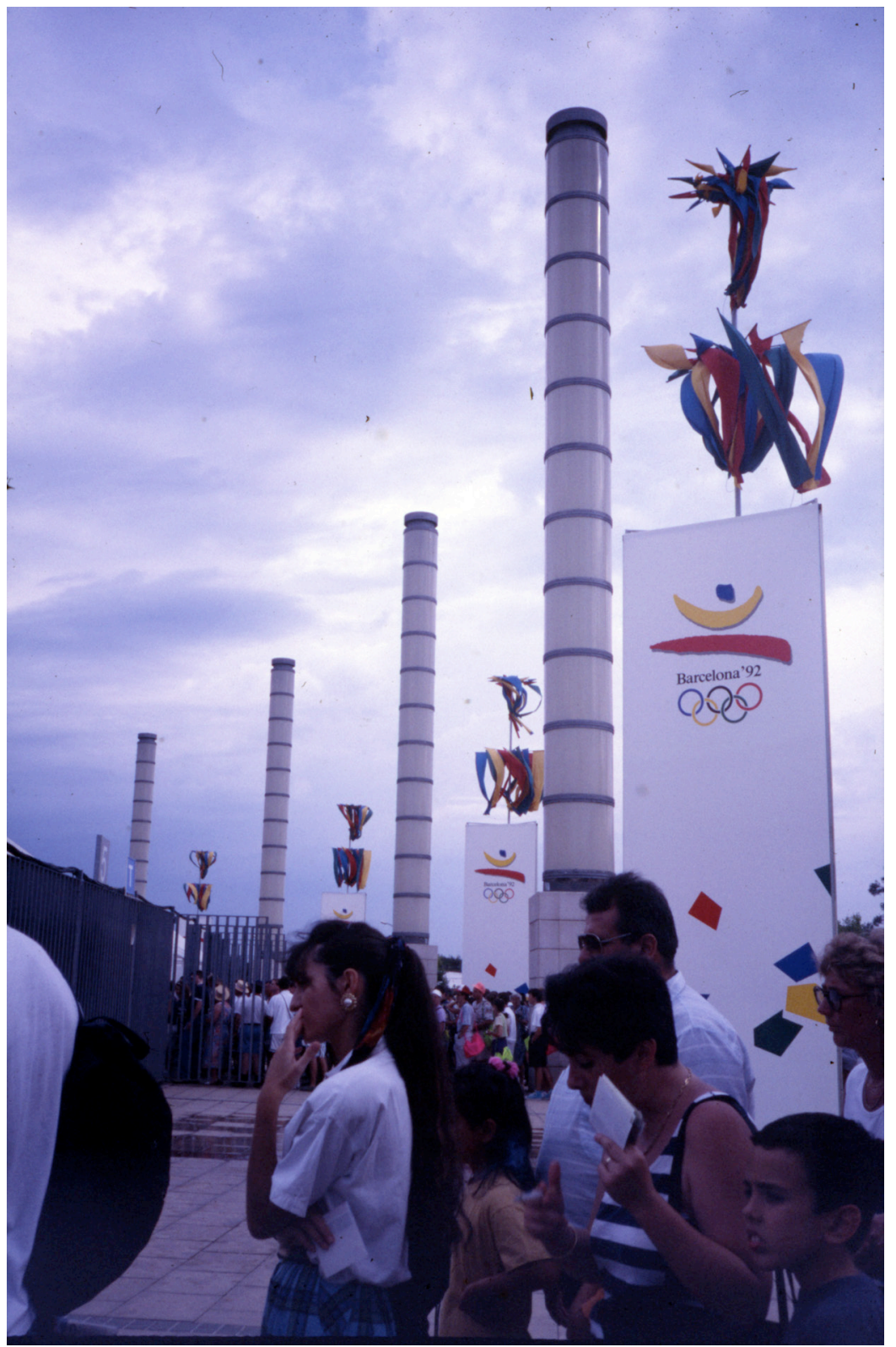

bered redesigning the component parts of the show-jumping hurdles, which were ordered from architects who had made a name for themselves in the redevelopment of the city, which took place in the years leading up to or during the Games themselves.

Lastly, Anna Calvera chaired the round table and, in light of the information that was presented there, she suggested to Jaume that they should prepare this article together, the aim of which is to shed light on what may be considered an early experience in Design Management, long before, in Barcelona at least, this concept was used naturally.
Figure 1. Bercelona' 92 visual symbols. Introducing the pictograph and the signals. Street decorations for Olympic areas summer 1992. Designed by design Studio Quod. Graphic designer: Josep M. Trías. Marketing department, Jordi Montaña. Pictures by the author, Private Collection. 
2. After the Games had ended, Jordi Pericot, then editor of the journal TdD Temes de disseny, published by the Elisava Design School, invited me to contribute to a monographic issue about the design of the Barcelona Olympic Games. This issue of the journal is still a landmark publication for the Games that complements the huge amount of "official" literature that appeared then. At the time I chose it to talk about the subject of the renewal of the souvenirs since the redesigning of the smaller things, done so successfully, had already caught my eye. Still available on-line.

3. This terminology was proposed by Norberto Chaves and Oriol Pibernat in an article that during 1987 made up the section "Encuadres" in the Sunday supplement of La Vanguardia newspaper. All these texts performed an important pedagogical function with regard to the normalization of the practices and the orders for design well done. It goes without saying that this pedagogical work of theirs was highly influential in the atmosphere favourable to quality design that so characterised Barcelona in the 1980s and 9os.

\section{Twenty-five years ago: daring to design}

[Anna Calvera] What I remember most about that time is a collective feeling, a mixture of euphoria, pride and happiness that was in the air everywhere you went. That rainy summer of 1992 I too was a spectator, excited but attentive to the development of the Olympic Games in Barcelona. I did watch it all; I observed, studied and commented on the many things that were done. I paid close attention to all the details that clearly showed how much care had gone into the organisation of the Olympiad and the Games. ${ }^{2}$ As an analytical observer, it soon became very clear to me that everything had been designed from the scratch, that creating design had been one of the most important political decisions made by the City Council in order to forge a new identity for the city. For it to be credible for everyone, the stylistic unity had to be guaranteed of everything used to show Barcelona to visitors, and the Olympiad to the citizens of Barcelona. It therefore seemed obvious that creating good design was regarded as the best and most effective way of showing how modern the city, and indirectly the country, had become since the political transition. You have to agree: for many and varied reasons, design continues to be a universal language that is interpreted in a very similar way everywhere, despite the many exceptions and objections that may have been made. Cobi, the Games' mascot designed by Javier Mariscal, the pictograph-symbol created by Josep M. Trias at the Quod studio (what is often called the logo, despite the fact that it is not a logotype but a brand image), the torch created by André Ricard, the flame holder by Bigas's team, and so many other things - the opening ceremony, the closing one, the materials created to present Barcelona's candidature, the TV advertisements, the buildings constructed for the event, the urbanism and the improvement of the infrastructures, the sea bursting in on people's lives in the city, and so on - all these things were fantastic ambassadors of the new Barcelona all over the world, just as the overall briefing demanded that they be. However, due perhaps to professional deformation, my attention was immediately drawn to the high level shown by the design of the smallest things, most particularly all the things that are so often considered unimportant, those in which it might seem unnecessary to invest money or pay too much attention to, because "it's not worth it; in fact, people don't even notice them", as it is so often said. And yet they are all those things that, when they "stick out like a sore thumb", in other words, when they go wrong because they have been badly designed, poorly made, or wrongly placed, then they really do get noticed! What is more, they get noticed so much that they can ruin the best setup. When they are good they often go unnoticed but there can be no doubt that they contribute crucially to the success of the whole thing: they ensure that the people feel it is a success without actually knowing why. Both then and now, these are the things that set the level that is achieved, they reveal what things behind the scenes are really like and they are the confirmation of what is promised by the graphic symbols that publicise them by applying a policy of corporate or organizational identity. Let's leave it then as design that is not eye-catching, that is barely noticed, but which is there and, therefore, enhances the city even though it may be on a small scale. We designers often refer to it as "transparent design". That the level achieved in the Barcelona Games by this transparent design was so high, that it had been possible to expressly design even the smallest detail, clearly shows that it was no coincidence but the consequence of a well defined 


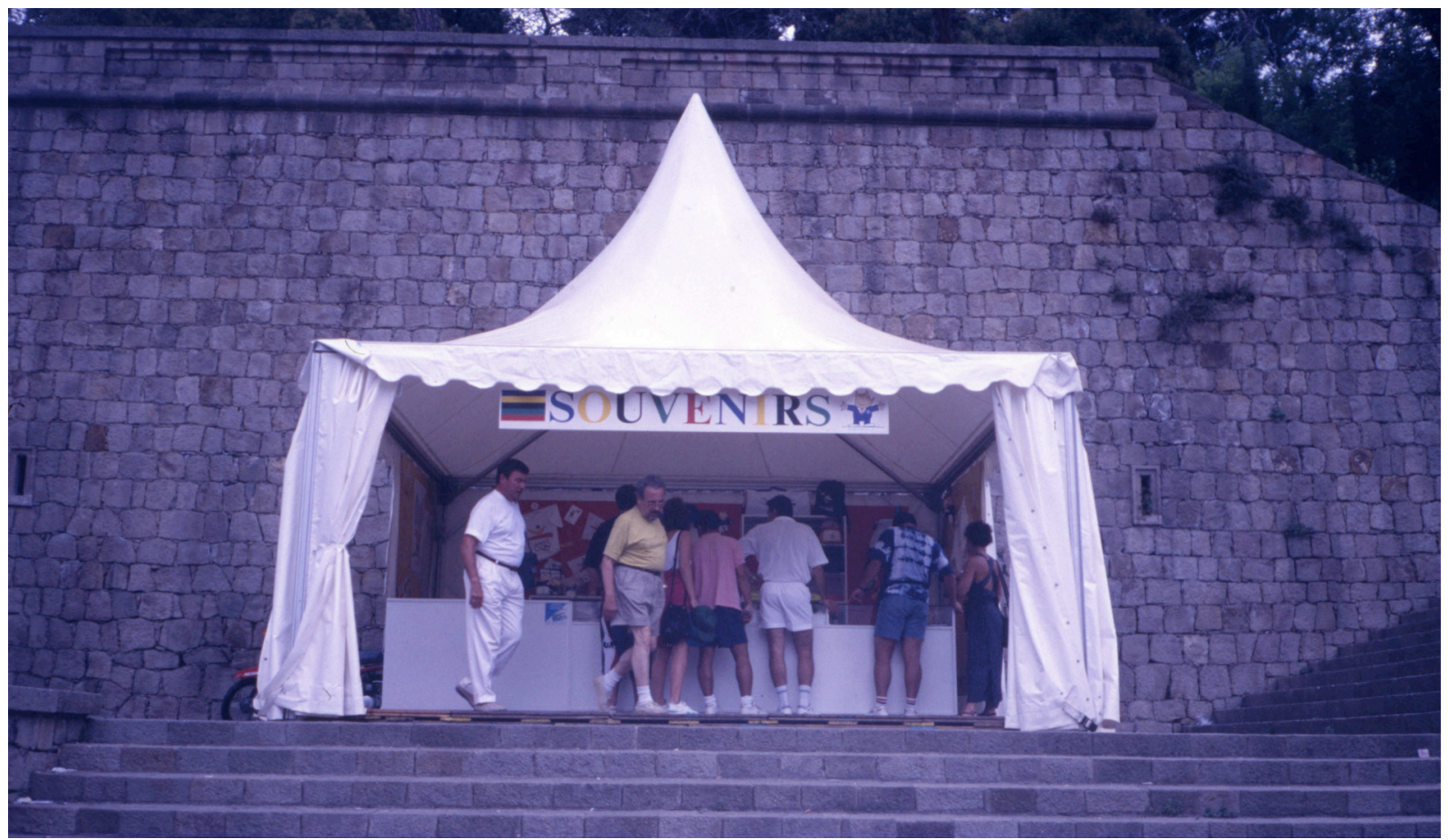

and very well managed institutional design policy, in which many people took part. We know that the Games were the work of a great team; several publications came out afterwards in which it was clearly explained. At the seminar Barcelona'92, a Design Olympiad, held in Barcelona in December 2012, it was clear that not only had there been a consistent and coherent design policy; it had moreover been systematically applied. Quite a lot of people had been a part of it but - and this is perhaps the most surprising thing from today's perspective - there was always tacit agreement about what had to be done, and thus several management departments and units, working with many different designers, were able to respect everyone's proposals and take advantage of their formal styles and working methods. Not only did this not spoil the consistency of the whole, it resulted in clear stylistic unity in all areas. It was therefore a true example of collective and coordinated design management. (Despite the fact that it might seem paradoxical, it is absolutely not: in fact it had happened once before in the history of design. It is the famous case of the corporate visual identity of the Italian company Olivetti to which many different artists and designers contributed by creating promotional and advertising materials for the company in Italy before the Second World War. It is the kind of stylistic unity that is achieved when what is shared is the same criterion of aesthetic quality - not formal or stylistic - and the willingness to achieve it. In the previous session of this same seminar, Javier Mariscal, talking about the corporate handbook created by J. M. Trias at the Quod studio, referred to it as "the joy of the white background". This is one of the details that most caught my eye back then: the omnipresence of the white background in everything referring to the Games. ${ }^{4}$ Indeed, when other colours appeared, such as the cyan-blue of the Mediterranean, the background gained semantic value and established the framework for a code that had to be expressly deciphered. Trias also confirmed this interpretation).
Figure 2. The White Background. A view of faire booth prepared as small shops everywhere to help visitors to facilitate people how to attend the games matches and stadiums. Photograph taken by the author in summer 1992.

4. This white is the basic subject of the article about the Olympic souvenirs in Calvera (1992). 


\section{The со०в's design management of Barcelona'92, some preliminary considerations}

[Jaume Masferrer, then соOB'92]. It is now 25 years since the Barcelona'92 Olympic Games, and therefore many people in Barcelona alive today did not experience them. Perhaps this is why it is worth, at the outset, giving an explanation that will help to highlight two big moments about managing and focusing on the public authorities' management of the games. It is the difference between an Olympic Games and an Olympiad. The Games last two weeks; an Olympiad is the four-year period between two Olympic Games. Barcelona hosted the 23rd Olympic Games but it was the 25th Olympiad: two editions had been lost due to the world wars. What I shall be talking about here are therefore the four years (1988-1992) of intense work done before the Olympic fortnight (25th July to 9th August 1992).

Barcelona changed with the games, from an unknown city to one known and loved the world over. It also became a better-equipped, modern, cosmopolitan city. The major infrastructures and services that we have today in Barcelona were made possible thanks to the Games: the ring-roads around the city and its outskirts; the first enlargement of the airport (which is now Terminal 2); the telecommunications towers, the one on Collserola designed by Norman Foster and the one on Montjuïc by Santiago Calatrava; optical fibre cabling in a Spanish city for the first time; the reclaiming of seven kilometres of beaches - before this, Barcelona had its back turned to the sea, as if it had no beaches! - and the appearance of a new leisure craft harbour, the Olympic Port; the recovery of the old working class district of Poble Nou and the building of the Olympic Village in the space between the very Old Town (known as Barrio Gótico by now) and the neighbourhood; the building of the Olympic Ring on Montjuïc, and the transformation of the Vall d'Hebron and Nou Barris poor people suburbs with other sporting facilities. Many of these projects had been planned for years but it was only possible to build them thanks to the economic impetus of the Games. There was a huge amount of investment concentrated in four years.

But more than anything, as a result of the Games, Barcelona had the most important publicity campaign in its history. To give just one example, a journalist from the Washington Post lived in Barcelona for a whole month to write an article for his newspaper about the city and its preparation for the Games. When he returned to the USA he entitled the report, "Atlanta, We Can Rest Easy". In it he wrote, "Our facilities (airport, communications, installations, etc.) are much better, better equipped and larger than those in BarceIona and we still have four years to build a Barri Gòtic, a Sagrada Familia, a Cathedral, a seafront with the sea and a harbour included, and a Park Güell!" In short, Barcelona was established on the international map, and also in the minds of the Americans and the people of many other countries, as one of the world's major tourist destinations (which is still so).

The direct and indirect economic impact of the Games was incredible, far in excess of the 1.05 billion euro budget for their organisation. The investment in public works, for example, was almost six times this figure and amounted to six billion euros. Other indicators to mention: unemployment fell from $18.4 \%$ in 1986 to $9 \%$ in 1992. In the ranking of the most suitable European 
cities to do business in, Barcelona went from eleventh in 1990 to fourth in 2010. According to recent studies, no other Olympic Games host city has been able to equal the economic impact that the games had on Barcelona; an impact that endured for the following ten years.

The Barcelona Games mixed public and private funding. It was the first time that this had happened. Los Angeles 1984 had been $100 \%$ privately funded whilst Seoul 1988 was $100 \%$ public.

The соов' 92 was the Games' organising committee. It had a mixed structure. Its president was the mayor, Pasqual Maragall, and the CEO was Josep Miquel Abad, a quantity surveyor in his professional life. Its Executive Committee was made up of Barcelona City Council (rooled by the Socialist party), the Generalitat de Catalunya (the autonomous government ruled by the conservative local party), and the Spanish Government (Socialist too). It is important to mention this: the Games got very disparate people and institutions sitting around the same table.

\section{Managing the Olympic design, what did it entail?}

[Jaume Masferrer]: Coordinating, directing and controlling the design of everything that could be designed. Besides that, doing it with criteria of usefulness, consistent with the image that we wanted to transmit of the Games, but above all of Barcelona: the Games are held in a city, ergo they are a unique opportunity to promote it! Right from the start, a Master Plan was drafted that was followed to the letter. It included all the targets - the what, the how, the who and the how much - that had to be met at all levels: sport, infrastructures, commerce, finances and also image. It was my job to direct and coordinate the Games' design, promotion and publicity programme with a major strategic objective: to help to promote Barcelona, its values and its creative capacity across the world. This was actually the real objective behind the Games. Therefore, the design strategy aimed to be consistent with a single basic principle, common to all the elements that were created: the brand was Barcelona and the goals of all this were to respect and promote the city's values through the promotional materials and the designs that were created. "It was the most important and motivating project of my life!"

To implement it, we had an internal team of 30 people, most of them very young, who gave up their jobs to embark upon a four-year project. They came from all the design and promotion specialities: there were designers, semioticians, ideas people...

We also had the help and the participation of many external collaborators, who had seen the Games as an opportunity to show the world their work and their talent. In the end, nearly 100 collaborators (external businesses and professionals associated with design, image and communications) worked with us. And they did it for Barcelona rather than for the Games: in that period, sport and design were not on very good terms, you might say! Maybe this has changed now. This was one of the CooB' 92 's most important roles: to get so many people involved. It was a driver, bringing together talent and people in a way that, since then, has never been seen in Barcelona. The city was full of talented and very able people - and it still is! 


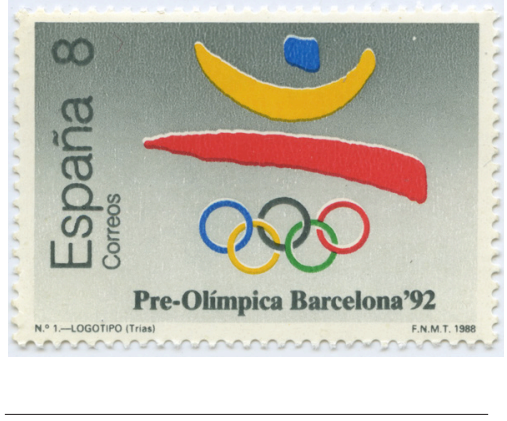

Figure 3. Bercelona' 92 visual symbols. Introducing the pictograph and the signals. Official Stamp for Olympic summer 1992. Designed by design Studio Quod. Graphic designer: Josep M. Trías. Marketing department, Jordi Montaña.

5. Red, Blue and Yellow in the saturated colours of the chromatic circle. These were the predominant colours in Barcelona throughout the 1980s. In 1981 the financial institution La Caixa had adopted them when painting Miró's star, which it adopted as its own brand image; in 1984 was launched a campaign advertising the town ("Barcelona more than ever before") and

addressed principally to the people of Barcelona. Its sign-emblem was a capital letter B drawn with a paintbrush, in which each stroke was in one of these saturated colours. Trias's logo and pictographs were completely in keeping with the style of the moment.

6. The model of pictographs established by Otl Aicher at Munich 1972 was very hard to improve upon or change. It directly inspired those of Barcelona that came from drawing the Munich pictographs with a paintbrush, and using the same structure and constructive principle when new signs are needed.
The image of the games step by step: signs, symbols, brands and signals. Now let's look more closely at some of the things that were done. Let's begin with the design of the brand image composed of a symbol (a pictograph) and a bland logotype (Barcelona'92) based on the design by Josep $M$. Trias. The colours of the logo (red, blue and yellow; or fire, sky/sea and earth) ${ }^{5}$ gave rise to the system of pictographs, "our" own pictographs. And I say "our" because we started from the scratch or, rather, we had them designed expressly based only on the pictograph. Since Munich 1972, it was the first time that special pictographs had been designed again for a Games, adapting them to the style of the entire brand image. ${ }^{6}$ With J. M. Trias / Quod we created 28 pictographs to indicate the events and more than 90 pictographs for the services, all of them exclusive to Barcelona.

These pictographs were the core element for the design of the Olympic signage programme. In this case, we were advised by the best specialist at the time, professor of Semiotics at he University, Dr Miquel de Moragas Spa (Moragas, 1995). He presented a plan for signs at all the Olympic facilities and for the 16 sub-venues, many of them outside Barcelona, such as the Olympic rowing canal in Castelldefels, a small town near the sea, and the traffic flows were forecast between any point of a venue and the different facilities. The aim was to inform the people, that we called the Olympic family, about access and mobility, and make it orderly. They were the athletes, trainers, committee members, journalists ... but also the general public.

Moreover, in Barcelona we had to deal with an additional complication, the various languages. We had four official languages: Catalan, Spanish, French and English ... and not exactly in that order! The solution was to write as little as possible: the less we resorted to the languages the better! We kept the proper names, as they were always written in one language only, but the remaining instructions were replaced with graphic signs - diagrammatic as designers often say - such as arrows to indicate actions and directions, and pictographs to represent, or replace, the common nouns of the language. Additionally, the Olympic signage had to coexist with the city's habitual regulation signage, which, it must be said, was still very limited then. In fact, as a result of the games it was necessary to review the signage policy of the whole city and especially of all the urban installations and facilities: railway and coach stations, the airport, the approach roads to the city ... it was crazy! The signs had fixed and temporary supports, short-lived actually. Some of them can still be seen: for example there are distance signs on the AP-7 motorways that say "Barcelona 92".

Another interesting project that was a variation on the logo was that of the Olympic look. It envisaged the decoration and dressing up of all the Olympic facilities, inside and out, so that they would also transmit the Barcelona brand. Apart from the "joyful white background", it incorporated two new graphic elements: a decorative frieze formed by a trencadis-type mosaic, reminiscent of Gaudí or Modernism, and a graphic figure inspired on the sea. Blue - a blue neither dark nor light but derived from cyan ink - was the main colour, sometimes the only one applied to the white background. In this project, one of the most outstanding elements (because building it was a high-risk project, perhaps?) was a large 


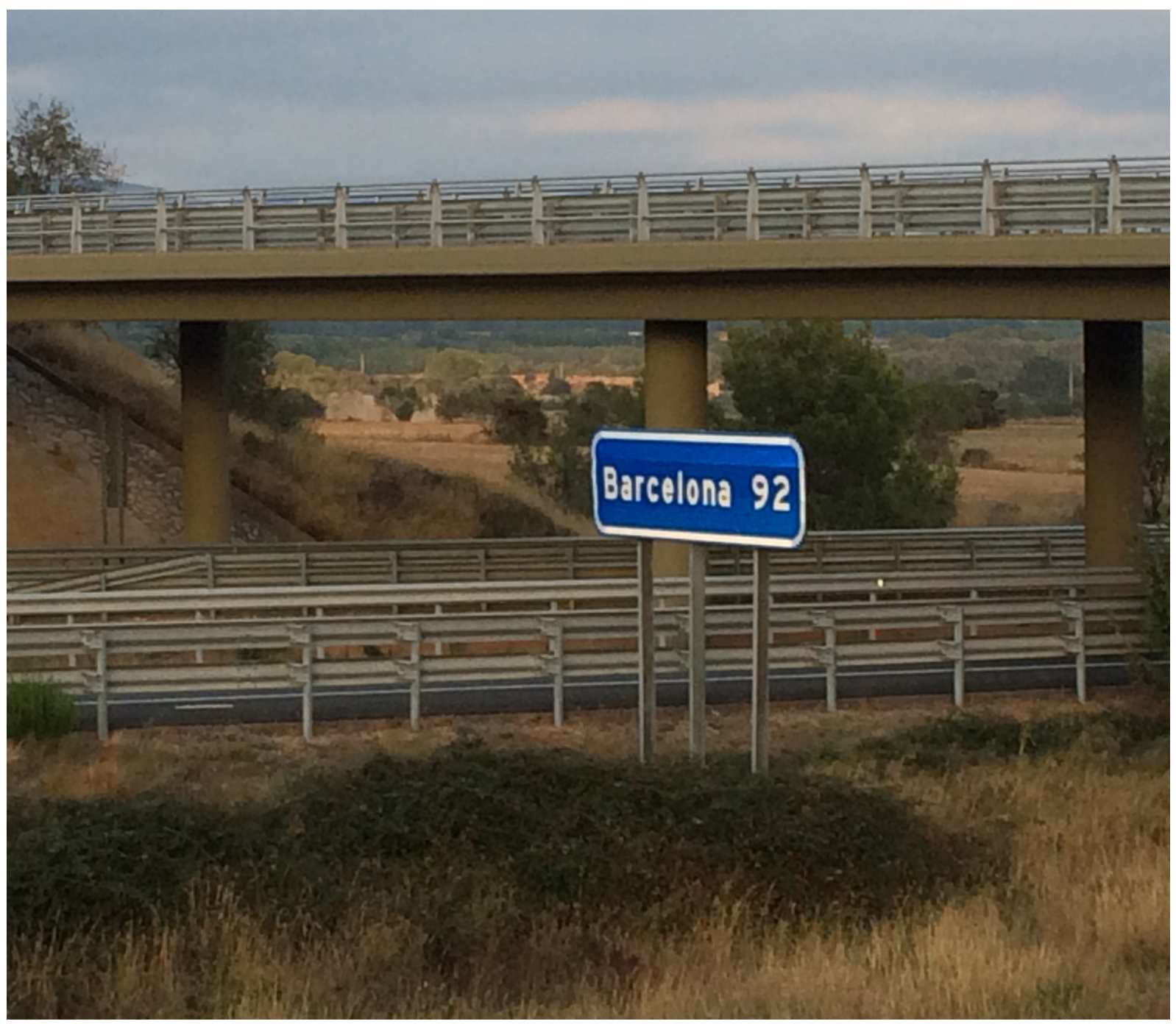

welcome arch erected over La Diagonal at the entrance to Barcelona, from which hung the flags of the 167 participating Olympic Committees. I consider it to be a record up to that time.

This Olympic look was designed to be seen and appreciated in situ as a single setting for all the facilities, but it also had to be seen in the television broadcasts of the Games made by every channel in the world. In fact, a little over two months before the start of the Games, on one of the control visits made by the president of the International Olympic Committee, he wanted to see what image of the city would be shown by the cameras when they broadcast the Games. We saw that it was necessary to enlarge the presence of the word "Barcelona" at every Olympic facility. It is hard now to imagine the upheaval that getting this done in time caused: we had to ask more than 100 Olympic volunteers to help with it.

The соOв'92 invested over 8 billion euros in the Olympic signage project and the look. More than 20,000 signs were produced.
Figure 4. Road signs. The only road sign left in 2016 placed in the motorway. While those placed in the road coming from north and south are disappeared, that one is still resisting in the road arriving from west. 
Figure 5. A Rethoric exercice: professionalise a mascot. Barcelona'92 most famous visual symbols, the Coby the Mascot. Designed by Javier Mariscal Studio, 1990; uses of Cobi as street sign. Private collection; pictures taken by the author in situ.

7. It is fair to say that, although Cobi is compared to and measured against the other Olympic mascots, in 1992 he had to compete with Heinz Edelmann's Curro, the mascot created in those same years - in fact, he was presented for the first time in 1989 - for the Expo in Seville, also in the summer of 1992. I think that the real dialogue was established between the two of them because they were both mascots designed by innovative designer draughtsmen, of great cultural value and with a lot of experience in the field of cartoons and comics. If comparing them is worthwhile, it is not for merely competing but to understand their graphic characteristics. For me, Curro lost the match and this is really surprising. He was far more orthodox than Cobi from all perspectives, a character designed bearing in mind the three dimensions and mobility in space, something that Cobi did not have and which ended up being a problem. Curro was very interesting graphically - and moving, evocative

- as he recalled, updating them, the spot colour cartoons that were so attractive and expressive in the film Yellow Submarine that Edelmann had made in 1967. In 1992, despite being completely up-to-date and even advanced, the mascot Curro's time had passed; what is more, Cobi had left him behind looking out-dated. In the history of graphic design and due to the analysis of effective graphic processes, the case is very interesting. It supplies data that go beyond the simple graphic quality to look deeply at problems of idiom and graphic conceptualization.

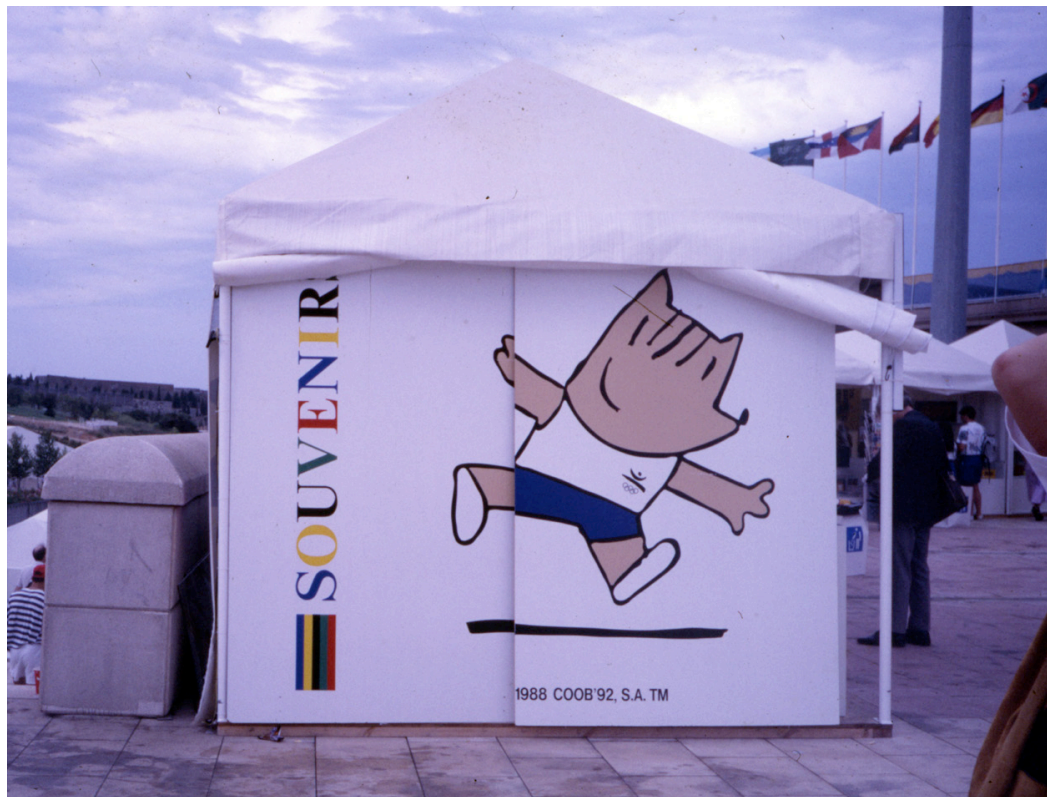

\section{Cobi, a different mascot}

Of this there can be no doubt: as a mascot Cobi was different. Although controversy broke out when he was presented in public, over time he has become the most famous and best-loved Olympic mascot.?

With regard to his conventional usefulness, facilitating contact with children, Cobi did a great job. He was also a very important source of income for the соов. All the sponsors used him in their respective campaigns, whether the companies were advertising their products or the services they offered. At the СOоB, Javier Mariscal drew customised Cobis for every company: we made Cobi drink Coca-Cola, make photocopies on a Xerox and take photos with a Kodak, drive a SEAT, make a phone call and use an IBM computer. This was besides many other activities such as, for example, carrying the Olympic torch all round Spain or doing all the sporting events. Over 100 licences to use Cobi were issued for more than 60 companies, and more than 800 products were manufactured with his image on them. Probably, one of Cobi's most innovative projects was to star in a cartoon series along with his friends, the Cobin Troupe. The El Tricicle group of mimics wrote the scripts for the series, Mariscal was the artistic director, and BRB the producers. It was sold to over 30 countries, to television companies such as the BBC and NHK in Japan and South Korea. He also appeared in a comic for young children published by Plaza \& Janés, an old publishing house in Barcelona. As far as we know, no other mascot has ever achieved figures like these. These were the four main design-based projects that were developed by COOB'92: brand image (logo and mascot), signage, the Olympic look and merchandising based on the mascot. Now we have to bear in mind questions of implementation. For the purpose of preventing wrongful use of the various symbols and graphic elements by the companies that had purchased the rights to use them, the соов published usage handbooks in which each and every one of the permitted application situations was stipulated. They were rigorously enforced. That and a very scrupulous legal department meant that both the logo and the mascot always appeared and transmitted an homogeneous standardised image. 


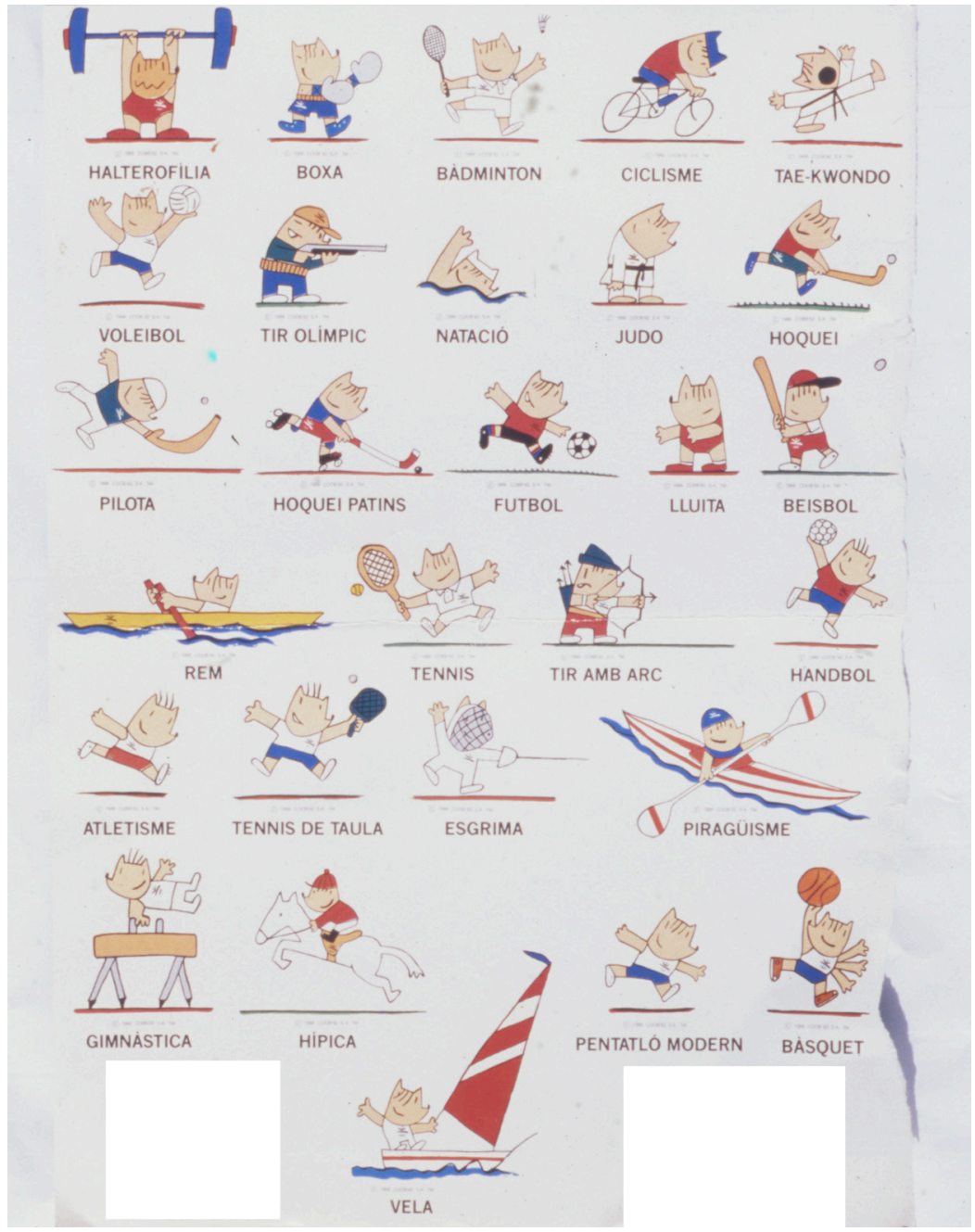

Besides the logo and the mascot, what else was designable? A series of products created specifically for the Games. For example:

The Olympic medals. Created by the sculptor Xavier Corberó. A detail: the Barcelona medals were the first to incorporate real gold in the material of which they were made.

The uniforms of all the соов employees. A habitual component in every corporate identity project, in this case the uniforms we designed were produced by Induyco \& El Corte Inglés.

\section{The dresses for the medal presentation ceremonies and the bouquets of}

flowers for the winners. These dresses were designed by Toni Miró. The bouquets were of ears of wheat: in the Mediterranean summer is the reaping season. The Olympic tickets. Hundreds of thousands of tickets for attending the events, distributed all over the world.

A stamp collection. Twenty-eight stamps were issued, one for each sport, designed by names such as Norberto Thomas and the painter Perico Pastor. It goes without saying that stamps had already been issued during the period of the Olympiad, featuring either the posters of the Olympic facilities or illustrations of the new buildings, many of them designed by the Villuendas+Cómez studio. ${ }^{8}$
Figure 6. A Rethoric exercice: professionalise a mascot. Barcelona'92 most famous visual symbols, the Coby the Mascot. Designed by Javier Mariscal Studio, 1990; reproduction of an old press advertisement introducing the mascot and the games. Private collection; pictures taken by the author in situ.

8. Twenty-five years after the event, present digital generation might not be familiar with postage stamps. For many years, the stamps with which people paid for the state postal service had been very good supports for advertising events that were being held in a place all over the country and abroad. They were a good advertising medium. 
9. For many graphic designers, creating a poster was no longer an easy task in 1992, not even if it was designed as a poster-souvenir, which was actually the real functional idea behind those posters. Very few poster of any kind were made then. Advertising posters had virtually ceased to exist, replaced by hoardings or enlarged newspaper advertisements linked to the television commercial. The cultural ones, relegated to the advertising columns in the street, were dying of starvation and lack of funding; they were not even bought any more as a substitute, or souvenir, of great cultural exhibitions - the reproduction of a painting by a great artist was better. The political parties now had other ways of running their campaign and their posters were reduced to selling a candidate's face ... not one single idea from a political or government programme appeared drawn and printed on paper. Educational posters, or for social awareness raising, were only seen inside the places where what they were saying was being dealt with: medical ones in hospital and doctors' waiting rooms, for instance. Tourist posters used the same old formulas and were gradually being replaced by videos projected on screens to be found everywhere. The exceptions to bear in mind are popular festivities. There were also public service posters through which the public sector publicised its services and ran campaigns with guidelines for coexistence. Going back to the Olympic Games, as a result of the competition for posters, the world of design began to talk about the poster again as a medium of communication, what a real poster was and what it had to be like. The old values deriving from its uses and communicative functions had gradually been left by the wayside and it was now time to rethink them. What was clear was the fact that the poster was no longer the number one medium of expression for graphic design. The whole collection is nowadays available at the Graphic design section of the Design Museum in Barcelona. For the complete list of creators of the published posters, see http://incom-uab.net/barcelonaolimpica/es/ barcelona92/disseny/cartells/
Poster collections. Several series were published. Two posters were unavoidable: the one that presented Trias/Quod's official logo and the one presenting Cobi, the corporate mascot, with his arms outstretched in a gesture of greeting, welcoming, and a "friends for life" type embrace, which was also used to advertise the Games' slogan and the promotional song. The publication of posters corresponded to a large, very ambitious programme by the соов that also reflected the wishes of professionals in Barcelona to collaborate with the event. They are therefore a demonstration of the COOB's capacity for pooling talent. It is worth mentioning it in detail.

Of the official posters, two more must be mentioned, the one by Antoni Tàpies and the one by Enric Satué. Both were the representatives of a collection formed on the basis of a corporate criterion. The one painted by Tàpies, then the most internationally famous living Catalan artist, acted as the official representative of the series "posters by painters". They had been commissioned directly to the artists on the occasion of the Olympic Games. Made in collaboration with the critic Daniel Giralt-Miracle, they included names of the stature of Chillida, Arroyo, Folon, Guinovart, Antonio Saura, Clavé, Llimós and Pérez Villalta. Eight of them were published.

The fourth official poster was by Enric Satué. This was the Barcelona Olympic Games poster, as the other two were badge-posters whose purpose was to present the other symbols; it was also the representative of the second series, that of "posters by graphic designers" (Trias, 1991). Heavily inspired by the style of Milton Glaser, on this poster Satué returned to Pop iconography and spot colours. He had won the restricted competition organised by the two representative bodies for design in town; the BCD (Barcelona Design Centre) and ADG FAD (the graphic designers association). It attracted $18 \mathrm{im}$ portant graphic artists at that time. Both Mai Felip and Arcadi Moradell, the competition organisers, were very careful to include the different generations of designers then active.

They were: Ricard Giralt Miracle, Josep Pla-Narbona, Enric Huguet, Tomàs Vellvé, Carlos Rolando, América Sánchez, Albert Isern, Arcadi Moradell, Vicenç Alonso and Lluís Ayguadé, Onèsim Colavidas, Claret Serrahima, Pilar Villuendas and Josep Ramón Gómez, Josep M. Mir, Quim Nolla, Pere Torrent "PereT", Salvador Saura and Ramón Torrente, Ricard Badía, Pati Núñez and Alfonso Sostres. ${ }^{9}$ Finally, the fifth series, very interesting from the graphic point of view, was about the sports. It was made up of 28 different posters done by a world famous English company, Addison, after winning a restricted competition. That project enabled it to win many prizes. Against a dark background, photos of the Earth taken from space appeared with photographs of sportspeople superimposed. They were quite spectacular. It may be thought of as the photographers' series, complementing the other idioms used to make posters. All in all, three million posters with the word "Barcelona" on them were distributed all over the world.

The Games' slogan: “Friends For Life”

[Jaume Masferrer] "Every great event needs a phrase to sum up its meaning and transmit values. We at the соов thought that our slogan had to sell Barcelona rather than the Olympic Games, seeing as the Olympic movement is a concept so well known that it doesn't need to be explained. I must confess that we found it very hard to find a phrase to define and position Barcelona, 

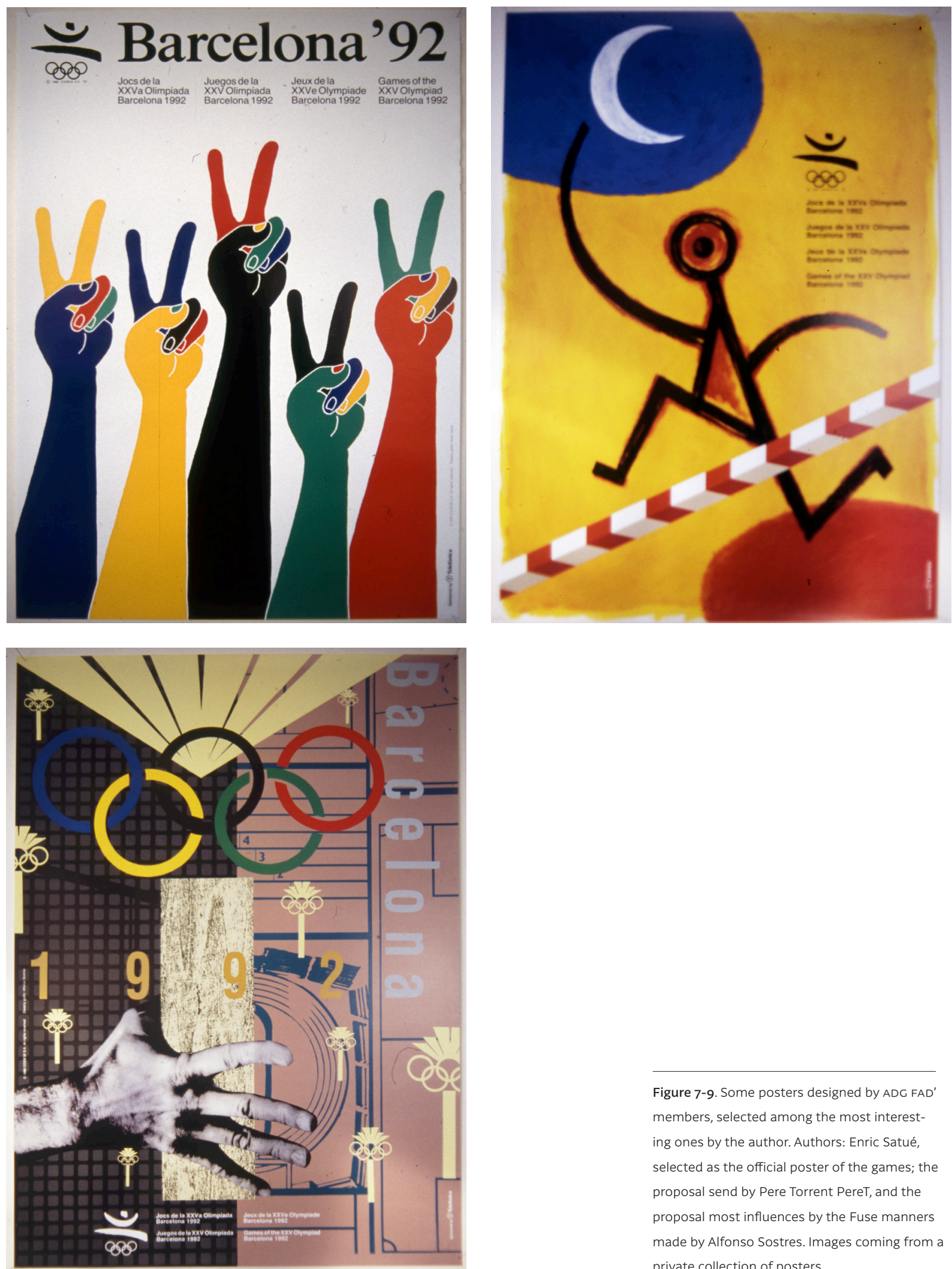

Figure 7-9. Some posters designed by ADG FAD members, selected among the most interesting ones by the author. Authors: Enric Satué, selected as the official poster of the games; the proposal send by Pere Torrent PereT, and the proposal most influences by the Fuse manners made by Alfonso Sostres. Images coming from a private collection of posters. 
because we wanted to avoid clichés. After much searching we chose the "Friends for Life" concept that a Dutch ideas man had come up with. It was a long process but it was a huge success. It expressed an invitation to get to know the city and take part in the Games. At the same time, it was a true statement: in Barcelona, when you make friends, they are for life. A very old Urban Legend confirms that widely.

The song Amigos para siempre (Friends for Life) was composed by Andrew Lloyd Webber, one of the most successful composers of musicals in the world, such as Cats and The Phantom of the Opera.

To promote the slogan and the song, just one year before the Games were due to begin, the соов managed to get an advertisement of the city broadcast on TV in more than 50 countries. Copies were distributed in all languages. On top of that, an advertising campaign was mounted in the United States with NBC, the channel that had all the broadcasting rights, for a sum in excess of six million euros."

And the Games arrived. They had to be opened... and closed.

[Jaume Masferrer] "We can say our job ended the moment the Games' opening ceremony began, in the evening of 25 th July, just when the arrow lit up the flame holder in the Olympic stadium. That ceremony is still considered to have been one of the best Olympic ceremonies ever.

The people responsible for it, Lluís Bassat's company and Pepo Sol's O'Video, entered the competition organised by the соOB'92 separately. In the end it was decided to take parts of the two projects presented and create the company OBS. The ceremonies were directed by the film director Manuel Huerga. He and especially the late Pepo Sol managed to produce what, in the words of Lluís Bassat, was the best advertisement for Barcelona: an advertisement lasting three hours which was broadcast to the whole world and reached an audience of thousands of millions of people for a total cost of just 18 million euros. It was however not an easy project. There were many difficulties: there was a serious likelihood of rain - that spring and early summer were exceptionally wet right up until just before the opening ceremony; the Spanish government was creating problems: for example, criticizing the performance of Camarón de la Isla, the great innovator of flamenco, because of the unhealthy life he was then leading; it imposed proportionality requirements for the Spanish, Catalan and Olympic messages. But there were also several memorable moments: the show by La Fura dels Baus, the word "Hola" formed by the volunteers welcoming the whole world, Josep Carreras' singing Amigos para siempre. All these things made the ceremony a resounding success. As you can see, there were a lot of projects, all very different, very stressful too. They were only possible thanks to the determination of many people, the capacity for teamwork, the great willingness shown, and the lack of sleep. All this without Internet, by the way! It all came together and succeeded, as the international press reported, in changing the way the Olympic Games were organised and transmitted. It was also a milestone in the use of design to give them a new image - in short, an example of success in a process of design and communications management. 


\section{References}

Calvera, A. (1992). El kitsch'92: la dignificació del souvenir olímpic/ Kitsch'92: Dignifying the Olympic Souvenir. Temes de Disseny, (7), 45-53.

De Moragas, M. (1995). Disseny, logotip i mascota en la promoció i la identitat de Barcelona'92. In: M. De Moragas y M. Botella (Eds.). Les Claus de l'èxit: impactes socials, esportius, econòmics i comunicatius de Barcelona'92 (pp. 115-129). Bellaterra: Servei de Publicacions de la Universitat Autònoma de Barcelona.

Trias, J. M. et al. (1991). Cartells olímpics oficials i collecció de cartells de dissenyadors. Barcelona: СоОв'92. 